\title{
危険な心電図
}

一そのメカニズムと対処方法一

Irregular Pulse in Electrocardiogram:

Understanding of the Mechanism

\section{藤田 博曉1)}

HIROAKI FUJITA, PT, MS ${ }^{1)}$

1) Department of Physical Therapy, Faculty of Health Science, International University of Health and Welfare: 2600-1 Kitakanemaru, Ohtawara city, Tochigi 324-8501, Japan. TEL +81 287-24-3000

Rigakuryoho Kagaku 20(1): 59-68, 2005. Received Dec. 9, 2004.

ABSTRACT: In the risk management of physiotherapy, electrocardiograms provide a lot of information. An irregular pulse is especially problematic in the clinical setting. The most important point physiotherapists must consider is when they should stop the therapeutic exercise or continue the exercise. In this report, we explain the basic criteria for understanding an irregular pulse, and explain the mechanism with an electrocardiogram.

Key words: arythmia, electrocardiogram, the therapeutic exercise

要旨 : 理学療法のリスク管理を行う上で, 心電図は多くの情報を与えてくれる。臨床において不整脈は特に問題とな るが, 理学療法士が問題として考える要点は, 運動療法を中止す心゙きなのか, 継続して様子を見て良いのかについて の判断である。本稿では, 不整脈の理解を助けるための基本的な知識に加えて, ダイヤグラムを用いて不整脈のメカ ニズムについて解説を行った。

キーワード：不整脈，ダイヤグラム，運動療法

1) 国際医療福祉大学 保健学部理学療法学科：杤木県大田原市北金丸2600-1（テ324-8501）TEL 0287-24-3000

受付日 2004年12月9日 


\section{I.はじめに}

現在, 理学療法の対象となる疾患はその幅も広くなり, 早期理学療法の必要性が求められている。そのため, 高 いリスクを抱えた状態で治療を進める場面が多くなって いる。このようなリスク管理を行う上で，心電図は多く の情報を与えてくれる。しかし，心電図については多く の理学療法士が苦手意識を持っているように感じてい る。

今回，このようなテーマを頂いたが，不整脈を理解す るための基礎的なお話をさせて頂き, 典型的な不整脈を 中心にそのメカニズムについて解説を加える。その中で, 心電図に関する苦手意識を少しでもなくして頂き，リス ク管理をふまえた積極的な理学療法の実践に役立つこと を期待している。

\section{II. 理学療法治療場面におけるリスク管理}

現在の理学療法における対象疾患は, 骨・関節疾患, 神経系疾患, 循環器疾患, 呼吸器系疾患, 代謝系疾患な どに分類されている。特に，心臓リハビリテーションに ついては, 診療報酬上の点数化やその範囲が拡大された ことを背景に施設数が増加している1)。また, 理学療法の 中心的な疾患である脳卒中患者では, 動脈硬化を基礎と した高血圧や不整脈などの高いリスクを抱えた状態であ る2)。従来の理学療法では, 急性期治療を終え一般状態が 安定した時期に理学療法を介入していた。しかし，現在 では早期理学療法が必要とされており, 発症直後の不安 定な状態から理学療法を介入することが多くなってい る。

このような急性期理学療法の治療場面において, 不整 脈の出現は頭を悩ませるリスク管理のひとつである。理 学療法士としてポイントとなるのは, 不整脈の出現して いる患者に対して，運動療法を継続するのか，あるいは 中止するべきなのか，直ちに判断することである。その ような判断をするためには，心電図を判読する能力だけ でなく，基礎心疾患についての情報を把握することが重 要となる。

\section{III. 理学療法士に必要な心電図知識}

運動による不整脈の発生機序を理解するためには，心 臓の刺激伝導系および正常波形についての理解が必要で ある。なかでも，刺激伝導系や心房や心室の関連，不応 期や受攻期に関する理解は重要なポイントとなる。

\section{1. 刺激伝導系}

心臟の刺激伝導系とは，心臓全体をリズミカルかつ効 率的に働かせるための特殊な線維である。この心筋の内 膜の近くを走る特殊な繊維は，他の心筋よりも電気刺激 を伝導する速度は10倍近くも速い部分であり, 一種の「高 速道路」のような役割を持っている。図1に刺激伝導系の 模式図を示す。右心房上方に位置する洞房結節から生じ た興奮は，心房，房室結節，ヒス束，右脚・左脚，プル キンエ纎維を介して心室に伝えられる。特に，房室結節 より下位の伝導系の働きにより，大きな心室全体を 0.08 秒という短時間で収縮することが可能となっている。

2. 正常心電図の基礎知識

心電図とは身体の表面から心臟電気的活動を記録した ものである。従って，図2に示すように，陽極に近づいて くる電流はプラス $(+)$, 陽極から遠ざかる電流はマイナ

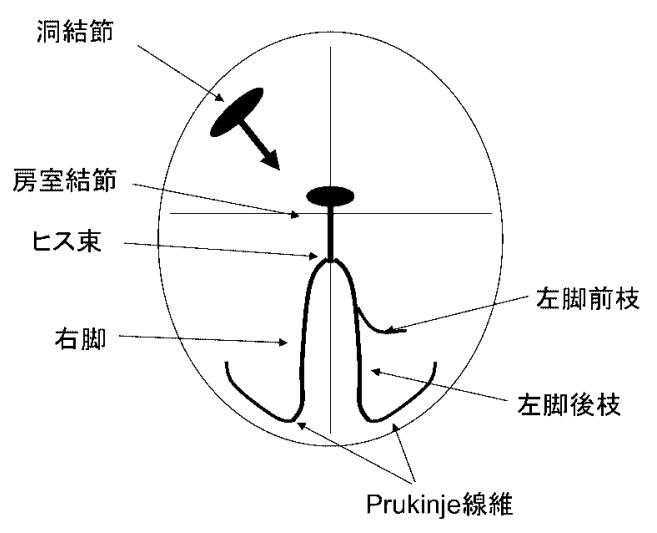

図1 心臟の刺激伝導系

A

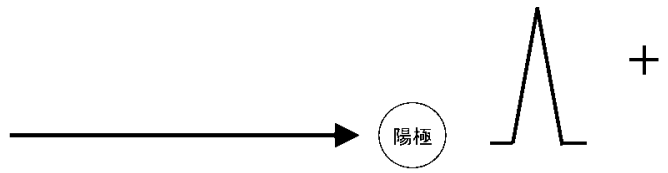

B
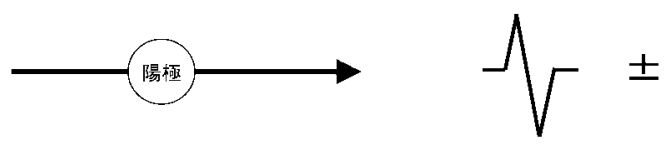

C 陽極

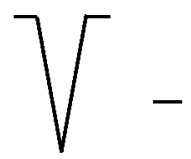

図2 電流の方向と心電図の波形 
ス（一）の波形として記録される。また図Cのように，陽 極が中間位においたときにはプラスマイナスの波形とし て記録される。今回, 電気軸についての解説は省略する が，刺激生成部位が異なるときには，波形に変化が生じ る事としてポイントとなる。

図3は心電計の記録用の目盛りの見方である。通常の心 電図記録では，1秒間に $25 \mathrm{~mm}$ の速度で記録される。その ため, 横軸の 1 目盛りは 0.04 秒を表し， $5 \mathrm{~mm}$ は 0.20 秒を表 している。縦軸は電位（電圧）を表しており, 特に記載 のない場合は10 mmで1 mVを表している。また, 図4に示 すように，時間の計測では上向きの波形の場合には，心 電図の下縁でその波形の始まりから終わりまで, 下向き の波形の場合には，心電図の上縁でその波形の始まりか ら終わりまでの時間を測定する。電位の高さを測る際に は，プラスの波形では基線の上からその波形の最上縁ま で計測し，マイナスの波形では基線の下から最下縁まで 計測する。今回取り上げる不整脈の理解のために必要な 横軸（時間軸）の正常值を示すが, P波は0.1秒以内, QRS 波は 0.10 秒以内, $\mathrm{PQ}$ 間隔は 0.12 秒以上， 0.20 秒未満（高齢 者では0.22秒未満）とされている。

\section{3. 心房と心室間の関係}

心房と心室は電気的には絶縁された状態にあり, 心房 から心室に興奮が伝わることはなく, 通常では房室結節 のみが唯一の通過可能な場所である。しかし, この房室 結節の伝導は非常に遅くなっている点が非常に特徴的で ある。図5に示すように房室結節の行う心房と心室との連 携は, 心電図上ではPQ間隔として表され, 心臟のポンプ としての機能としては非常に重要である。つまり, 心房

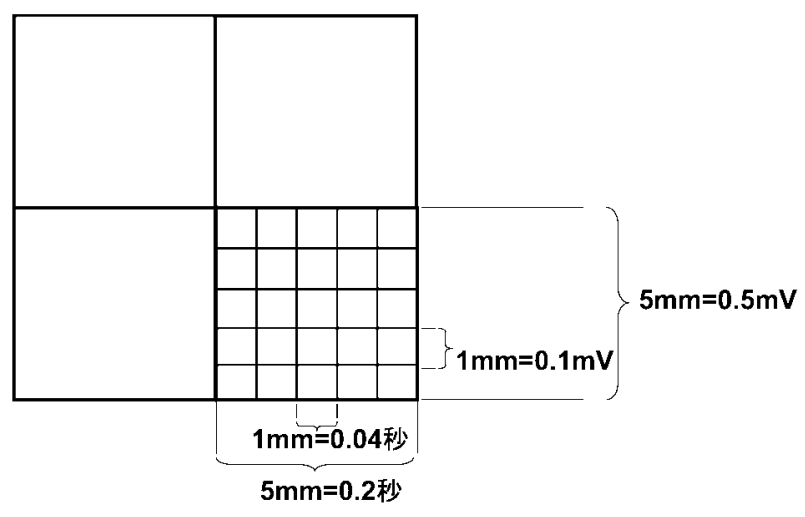

通常は記録紙の搬送スピードが1秒間に $25 \mathrm{~mm}$ で行われる。

横軸: $1 \mathrm{~mm}=0.04$ 秒、 $5 \mathrm{~mm}=0.2$ 秒

縦軸: $1 \mathrm{~mm}=1 \mathrm{mV} 、 5 \mathrm{~mm}=5 \mathrm{mV}$

図3 心電計の記録用紙の見かた

の収縮によって送られた血液は心室内に送られるが，房 室結節が存在することで「間」を生じる事ができる。こ の「間」が存在することで, 心室は充分に血液を貯めて から収縮することが可能となり，心臟のポンプ機能の効 率化という面で非常に重要なポイントである。PQ間隔の 正常值は 0.12 秒から 0.20 秒といわれているが, この值が長 すぎるとブロック，短すぎると副伝導路の存在が疑われ る。

4. 不応期と受攻期の存在

不応期とは一つの刺激が筋肉を通過した後で, 次の刺 激が来ても反応しない一定の時期を意味しており，心臓

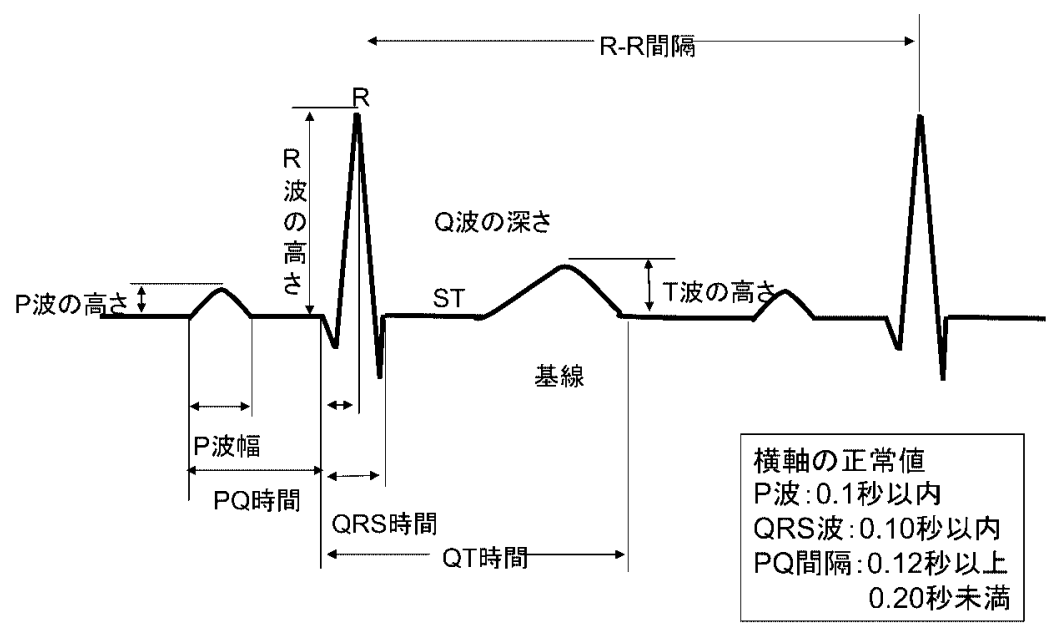

図4 正常心電図波形とその計測点 


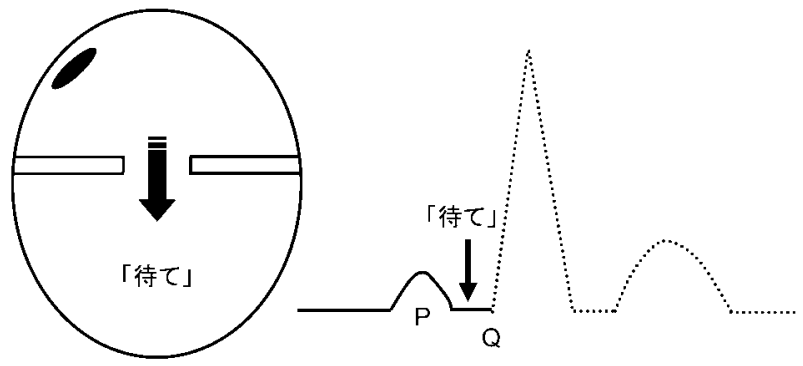

図5 心房と心室の関係

心房が収縮して心室が収縮するまでに, 房室結節が「待て」と 時間をかけることで，心房収縮により心室に送られた血液が， たっぷりとたまった状態で心室が収縮するという, ポンプ効 率を生み出している.

に特異的な電気的活動である。図6に示すように, 不応期 には「絶対不応期」と「相対不応期」に分けられ, 前者 はどのような強い刺激がきても反応しない時期であり, 後者は普通より強い刺激が来たときにのみ反応する時期 と説明されている。また, 不応期の長さは心筋の部位に よって異なるが, 脚ブロックやリエントリー, 心室内変 行伝導などに関連し, 不整脈の理解のためには重要な概 念である。ちなみに右脚と左脚を比べると, 右脚の不応 期が長いとされている。そのため, タイミングに異常刺 激が発生すると右脚のみが反応できないことになる。こ のメカニズムは, 右脚ブロックの形をとる「心室内変行 伝導を伴った上室性不整脈」のメカニズムとして後述さ せて頂く。

また, 受攻期と呼ばれるT波の頂上付近では細胞閾值 が低下しており，興奮レベルが乱れやすい時期とされて いる。この時期に期外収縮が発生すると R on T型の期外 収縮と呼ばれ, 心室細動へ移行しやすい重篤な不整脈と いわれている。

\section{IV. 危険な不整脈}

表1は不整脈の危険度別のランク付けと治療の要点を まとめたものである。このランク付けではAからB・Cへ と, その重症度が重いことを意味しており, 特にCランク の不整脈はトレーニングを中止することはもとより，生 命に影響を与える重篤な不整脈である。また，Aランク の不整脈では直ちに運動の中止とはならないが，注意を 要する不整脈となっている。特に, 運動量の増加に伴っ てAランクからBランクへの移行する場合には, 運動を中 止すべきと判断するべきである。

今回, 不整脈の理解を助ける手法として, 図7に示すよ

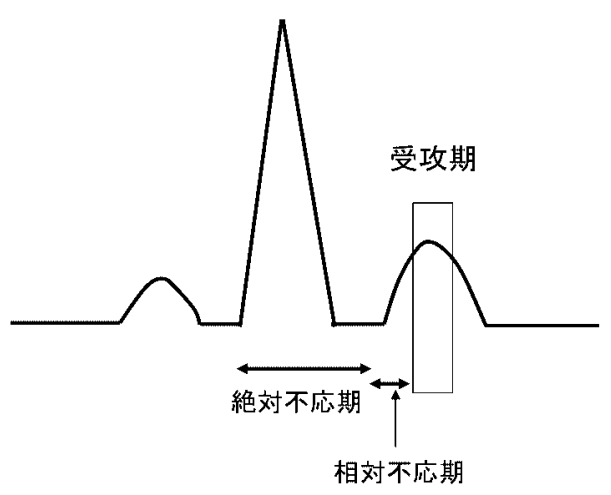

図6 絶対不応期と相対不応期について 絶対不応期とはどのように強い刺激に対しても反応し ない期間であり, 相対不応期は普通より強い刺激が来た ときのみ反応する期間. 受攻期とは心筋の興奮レベルが 乱れやすい時間をあらわす。

表1 不整脈の危険度別ランク付けと治療の要点

A）治療を要する不整脈

(1) 上室性期外収縮

(2) 心室性期外収縮で頻発性・多形性・short run など

(3) 慢性の頻脈性心房細動

(4) 発作性心房細動

(5) 上室頻拍

(6) 心房粗動

(7) Wenckebach 型房室ブロック

(8)心拍数が正常に近い慢性の房室ブロック

(9) sick sinus syndrome

B）危険性が大で死に至る可能性のあるもの

(1) R on T 型の心室性期外収縮

(2) 心室頻拍

(3) 失神発作のある sick sinus syndrome

(4) 失神発作のある Mobitz・型房室ブロック

(5) 完全房室ブロック

C）致命的で直ちに処理を必要とするもの

(1) 心室細動

(2) 心停止

うな「ダイヤグラム」をもとに解説を加える。このダイ ヤグラムの書き方は,

(1) 心電図の基線に平行に等間隔の4本の線を書く。

(2) 心電図のP波の始まりと, QRS の始まりに一致する 間隔で心房, 心室の興奮に相当するように縦線を引 $<。$

(3) 心房と心室の間をつなげるようにして房室接合部 を斜めに記入する。 


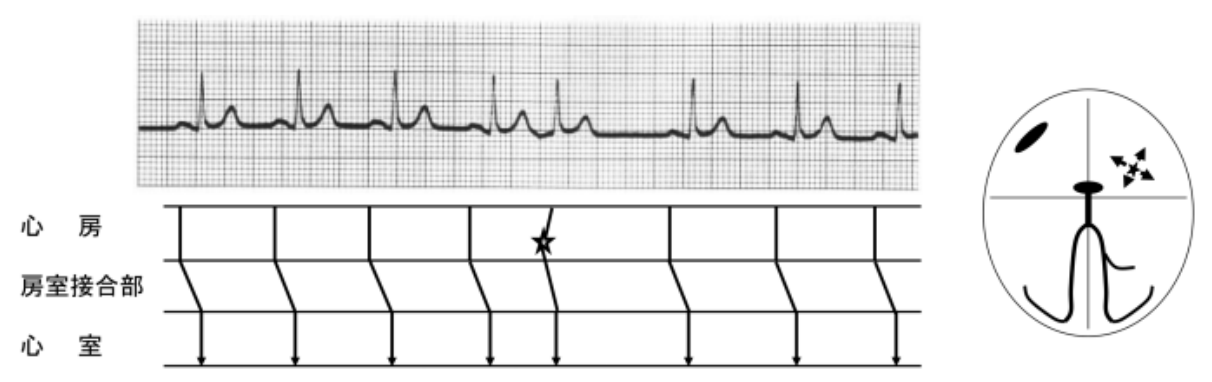

図7 上室性期外収縮の発生のメカニズム

1拍目から4拍目までは正常伝導.5拍目は正常リズムより早期に心房内で刺激発生している. 心房内下部から発生しているため, P波は陰性波を示している.また, 房室接合部以下は通常 の経路を通るので, QRS波は変化していない.（文献5）のものを改変）

(4) 期外収縮などのリズム異常を見つけた際には，異所 性刺激の発生部位に「れ」を付け，そこからの興奮 伝導の過程を記入する。

このような手順でダイヤグラムを記入することで, 種々の複雑な不整脈についての理解を助け, 心房と心室 の関係や刺激伝導系の異常を理解するのに非常に便利で ある。

以下に代表的な不整脈を紹介し，そのメカニズムにつ いて解説を加える。

\section{1. 期外収縮（premature contraction）}

(1)上室性期外収縮

(supraventricular premature contraction : SPC or APC)

上室性期外収縮はその刺激生成部位によって，心房性 と房室接合部性に分けられているが, 両者の区別は困難 なことが多く，まとめて上室性期外収縮と呼ばれる。診 断基準としては，基本調律のP波よりも早く $\mathrm{P}$ 波が出現し ているが，正常調律と同じQRS波が出現することで鑑別 が可能である。

図7に示すように, 4拍目までは洞調律によるP波や正常 のPQ間隔，続いてQRSが続いている。しかし，5拍目は それ以前のリズムよりも早期にQRSが出現しており，そ れ以前のQRS と幅や形が同様であるため, 心室の伝導系 には異常がないことを表している。また, よく見ると5拍 目のQRSの前には陰性のP波が出現しており, 上室内で早 期に出現した異所性刺激であると判断される。通常，上 室性期外収縮だけでは治療の対象とはならないが，多発 するような症例は心房細動に移行しや寸いので注意が必 要である。

(2)心室内の変行伝導を伴った上室性期外収縮

(intraventricular averrant conductuon : averrant)

判断の難しい上室性期外収縮として心室内の変行伝導
を伴った上室性期外収縮があげられる。これは不応期の ところで述べたように, 右脚の不応期が長いために生じ るものであり, QRS波が変形して右脚ブロックの形とな る。

図8に示すように4拍目までは正常調律であり5拍目に 幅の広いQRSが見られている。そのため，心室性期外収 縮と見まちがえやすいが，5拍目の直前には変形したP波 が確認できる。これは比較的早期に発生した期外収縮の ため，4拍目の右脚の不応期に重なったことが原因であ る。

\section{(3)心室性期外収縮}

(ventricular premature contraction : VPC)

心室性期外収縮の大きな特徵は，P波が先行しないこ と, 幅の広いQRS波とそれとは逆向きの大きなT波とされ ている。

図9に示すように, 1拍目から3拍目までは正常リズムで あるが, 4拍目の心房からの伝導が心室に伝わるよりも早 期に心室内で異常刺激が発生している。また，心室内か ら刺激が発生するため, QRS波は幅が広く変形している。 ダイヤグラムをみると，心房からの刺激は正常に行われ ているが, 房室接合部で打ち消されていることがわかる。

心室性期外収縮は理学療法室でもよく見かける代表的 な不整脈である。この期外収縮は心臟のポンプ機能を考 えた場合, はるかに病的な意義は大きく, 一回拍出量を 減少される不整脈である。したがって, その発生頻度と 種類によって重症度が判定され, Lownの分類が一般的に 用いられている。しかし，Lownの分類は心室性期外収縮 と突然死の関係を調査したものであり, grade 5 とされて いるR on T型が必ず心室細動や突然死に結びつくとは言 えないようである。また, 運動と心室性期外収縮の関係 で見ると, 安静時に心室性期外収縮が出現していても, 運動を開始し心拍数が上昇することで心室性期外収縮が 


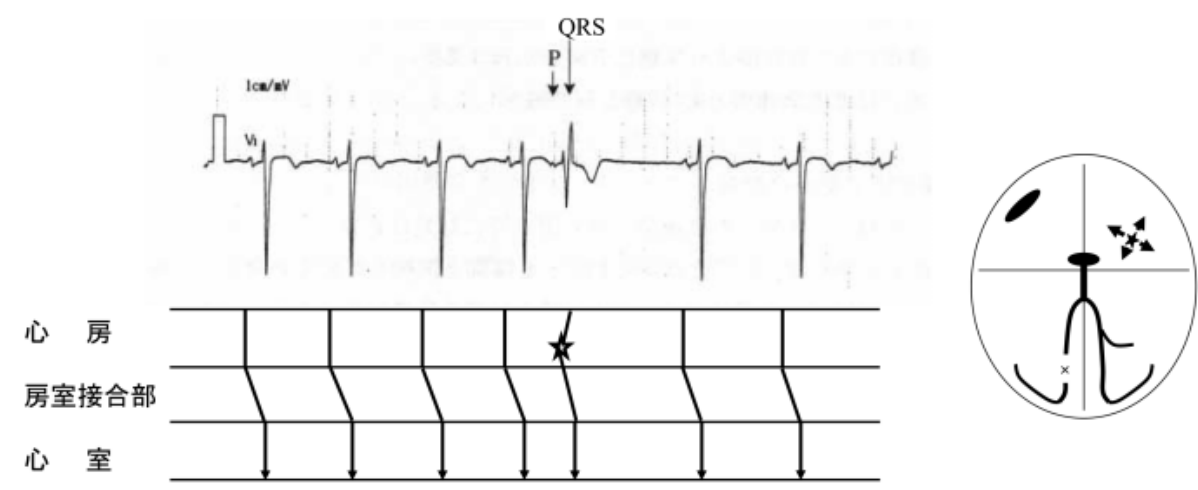

図8 心室内変行伝導を伴った心房性期外収縮

4拍目までは正常調律.5拍目に幅の広いQRSが見られ，一見心室性期外収縮と見られやすい が，P波が確認される．4拍目の右脚の不応期に重なったため，QRS波が変形している.（文献 4）のものを改変)
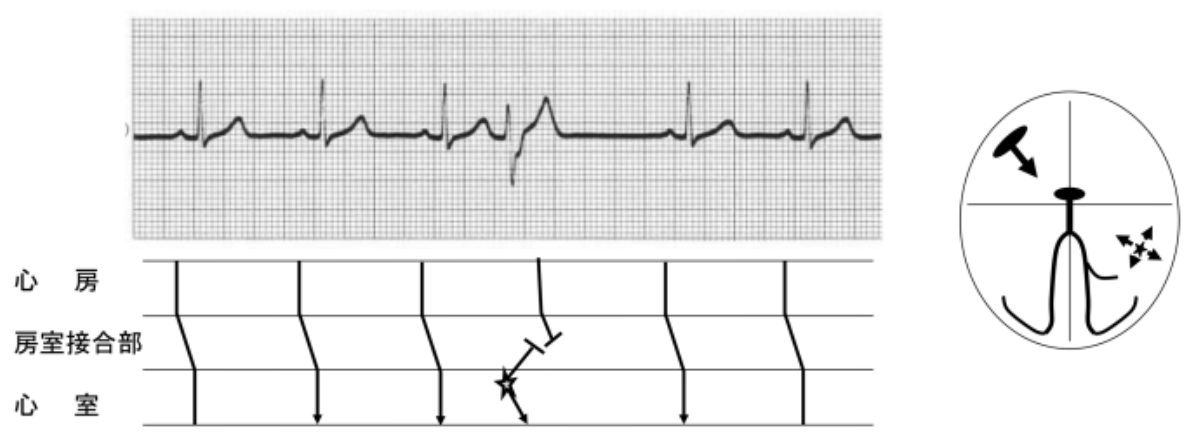

図9 心室性期外収縮のメカニズム

1拍目から3拍目までは正常リズムであるが，4拍目はP波が見られず，幅の広いQRSが見られ ている。つまり，心房からの伝導が心室に伝わるよりも早期に心室内で異常刺激が発生して いる.なお，心房からの刺激は心室筋の不応期にあたるため，房室接合部で打ち消されてい る.（文献5）のものを改変）

表2 修正Lownの分類（1974）

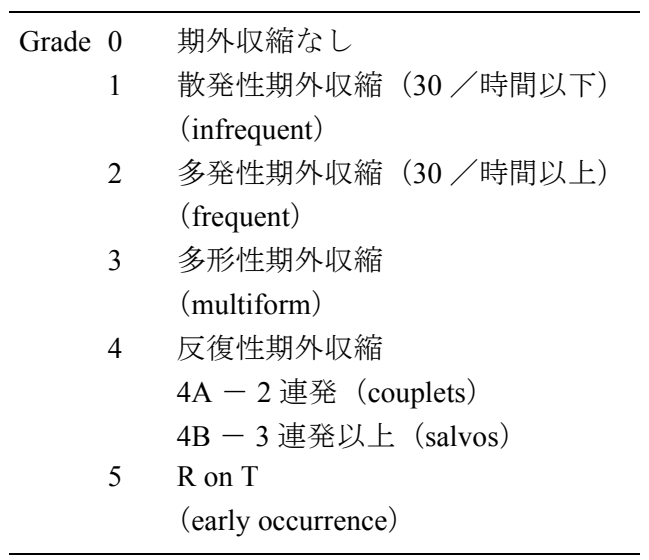

減少する傾向があると報告されている3)。

また，図10にR on T型のメカニズムを示すが，T波の頂 点は「受攻期」と呼ばれ，電気的に不安定な時期とされ ている。この時期に不整脈が発生すると, 反復性の興奮 を引き起こしやすく，心室性頻拍になりやすいといわれ ている。

理学療法士としては，あくまでも基礎疾患に由来する ことを考え，少なくともgrade 1 の散発性の場合には，様 子を見ながら運動を継続し, 運動によりその頻度が増加 する場合やより重症なタイプヘと移行するかどうかを見 極める事が必要である。ただし, 単発性から多発性（心 室の複数の場所から異常な刺激生成が起こるもの）への 移行, あるいは2段脈や3段脈（正常調律の対する以上調 律の頻度で表される）へと移行する場合には, 直ちに運 動療法を中断し主治医に相談するべきである。 
2. 房室ブロック（atrioventricular block : A-B block)

房室ブロックは洞結節からの刺激が房室結節の部分で 伝導障害を起こし，心房と心室の間で伝導障害が発生す る状態をいう。その伝導障害のタイプによって, 次に述 ベる3種類に分類されている。

(1) I度房室ブロック

心房から心室への伝導に, 単に時間的な遅延が生じて いるものである。図11に示すように，心電図上ではPQ間 隔の延長として表れ, 正常PQ間隔は0.20秒以内であるが, 0.20 秒以上に延長しているものをいう。(なお，高齢者で は0.22秒以上が異常と定義されている。）極端な除脈とな らない限り，I度房室ブロックだけでは運動療法には影響 を与えないと考える。

(2) II度房室ブロック

II度房室ブロックは心房と心室の伝導がときどき途絶 するもので, ブロックの出現のしかたで次の2種類に分け

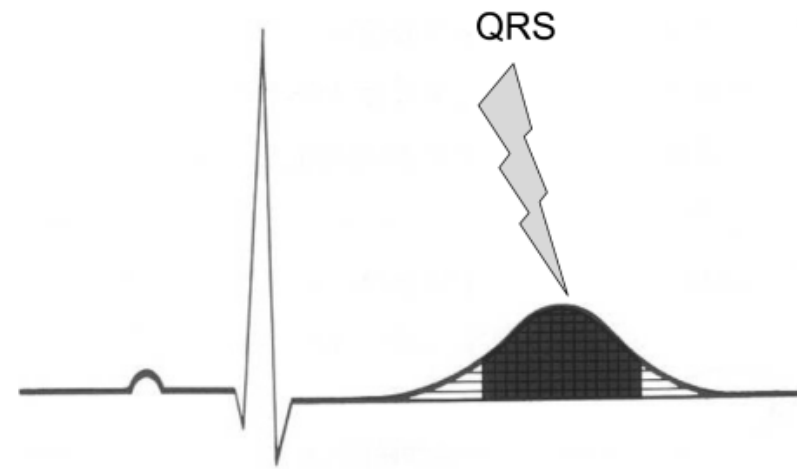

図10 R on Tのメカニズム

T波の頂点に存在する「受攻期」は電気的に不安定あり， 電気的に過敏に反応寸る時期である.この時期に期外収縮 が発生すると, 反復性に興奮を生じ, 心室細動を起こす可 能性がある。（文献5）のものを改変）
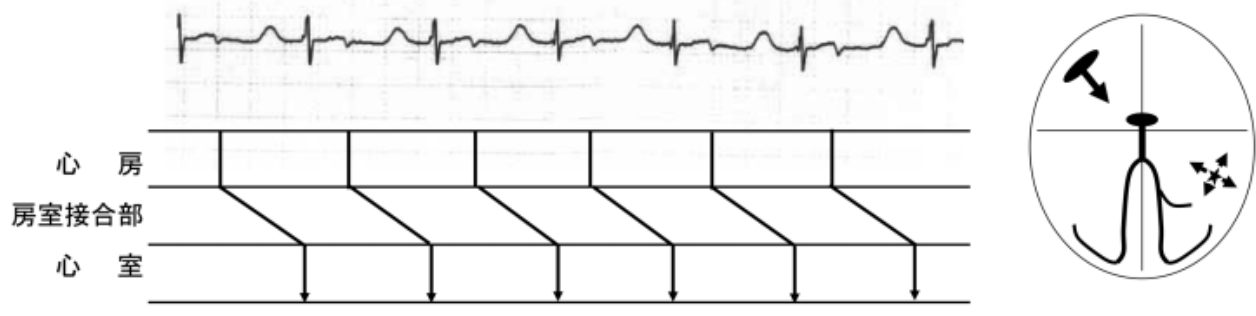

図11 I度房室ブロック

心房から心室への伝導に遅延があるもの，心電図上ではPQ間隔の延長として現れる．P-Q間隔の正 常値は $0.12 \sim 0.20$ 秒であり, 0.20 秒以上の延長をもって診断される. (なお, 高齢者では 0.22 秒以上 と定義されている)
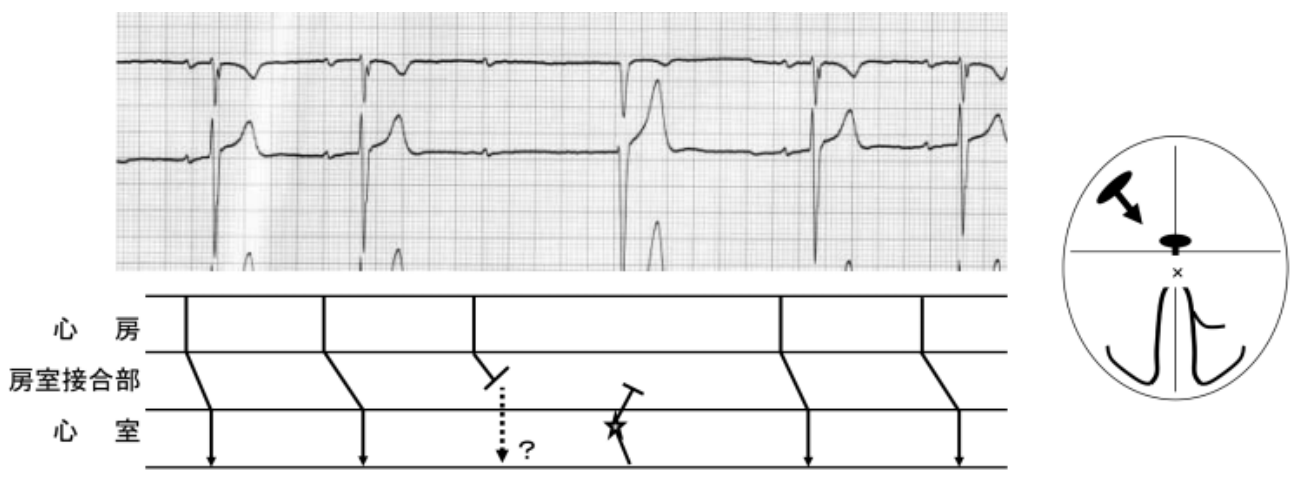

図12ＩI度房室ブロック（Wenckebach型）

PRは1心拍毎に次第に延長し，ついには房室伝導が途絶するが，次にはまた伝導が回復する周期をく り返す。(なお,ブロックの後は心室から補充収縮が発生している) 


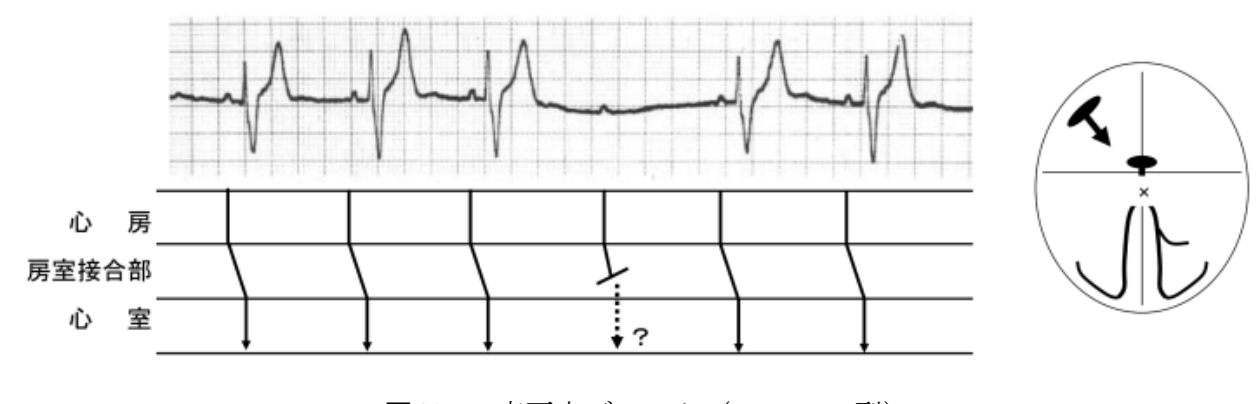

図13 II度房室ブロック（Mobitz・型）

1拍目から3泊目までは正常洞調律である.PQ間隔も変化はないが，4拍目で突然QRSが久けてい

る.（QRSの幅が広いので，心室内伝導障害の関与が考えられる）（文献6）のものを改変）

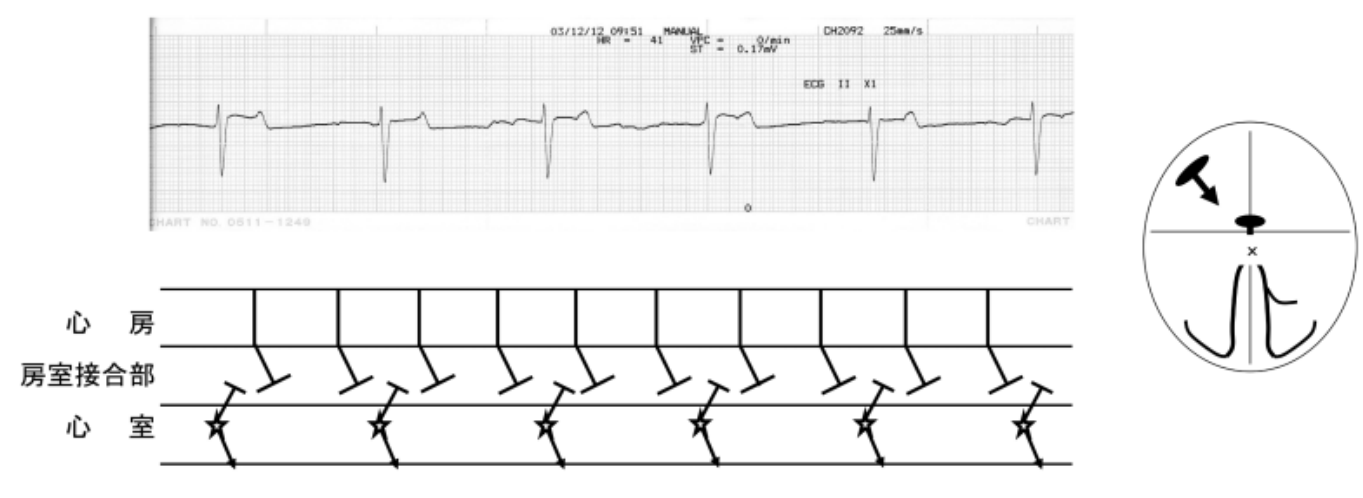

図14 III度房室ブロック

P-Pの間隔は一定であり，R-R間隔もそれぞれ一定である.よく見ると両者はそれぞれ独立したリズム を有しており，両者には電気的つながりが見られない。

られる。

\section{a) Wenkebach型}

PQ間隔が1拍毎に延長してゆき，ついに途絶するもの。 図12に示すように，心電図上では1拍目よりも2拍目はPQ が延長しており, その次ではP波のみが出現しQRSは欠落 している。また，その後は伝導が回復しており，このよ うな周期をくり返すことを「Wenkebach周期」という。 Wenkebach型房室ブロックは健常者でも見られることが あるが，ジギタリス剤を服用している患者ではジギタリ ス中毒を疑い，濃度をチェックすることなどが必要とな る。発見した場合は医師に報告が必要となる不整脈であ る。

\section{b) Mobitz II型}

このタイプでは房室伝導が何の前ぶれもなしに途絶す るものをいう。図13に示すように，3拍目までは一定の間 隔で房室伝導が行われているが，4拍目ではP波のみが出 現しQRSは欠落している。このように, 前ぶれもなしに 伝導が途絶し，P波に続くべきQRSが久落するのが特徵
である。ダイヤグラムでも PQ間隔の変化がなくQRSが欠 落していることがわかる。Mibitz II型はより高度な房室ブ ロックに移行しやすいことから，Wenkebach型より予後 は不良であるといわれており，発見した場合は直ちに医 師に報告する必要がある。

(3) III度房室ブロック

心房と心室の間にはなんのつながりを持たない状態で あり，心房と心室の収縮がお互いに全く無関係に起きて いるものである。洞結節や心房の活動が房室接合部周囲 で完全に遮断されているため, その活動電位は心室には 伝わらない。そのために心室では補充収縮が出現し，心 房と心室がそれぞれ独立した周期で活動をしている状態 である。したがって補充収縮で補っている状態であるが， 補充収縮がでないときには心拍出量が低下寸ることから Adamus-Stokes発作を起こしやすく，人工ペースメーカー の適応となる。

図14に示すように，心電図上ではP-P間隔やR-R間隔は おのおの連続性が見られるが, P波とQRS波の間には規則 

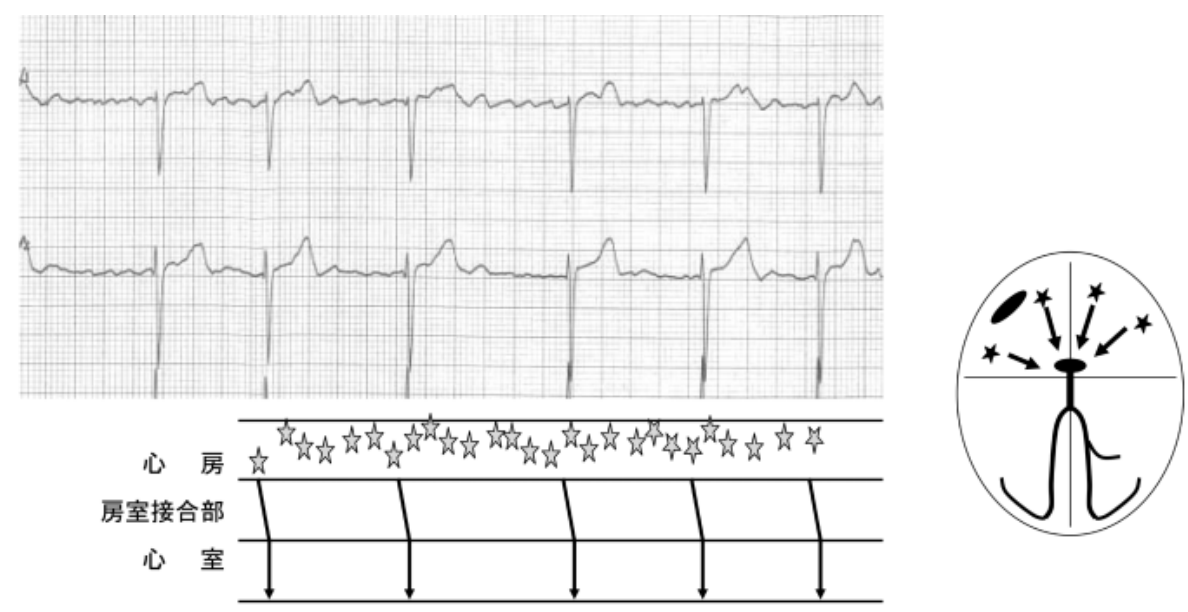

図15 心房細動発生のメカニズム

心房内で無秩序に刺激が発生しているため, 有効な心房収縮はできない. そのうちのどれか が，たまたま心室を収縮させる。
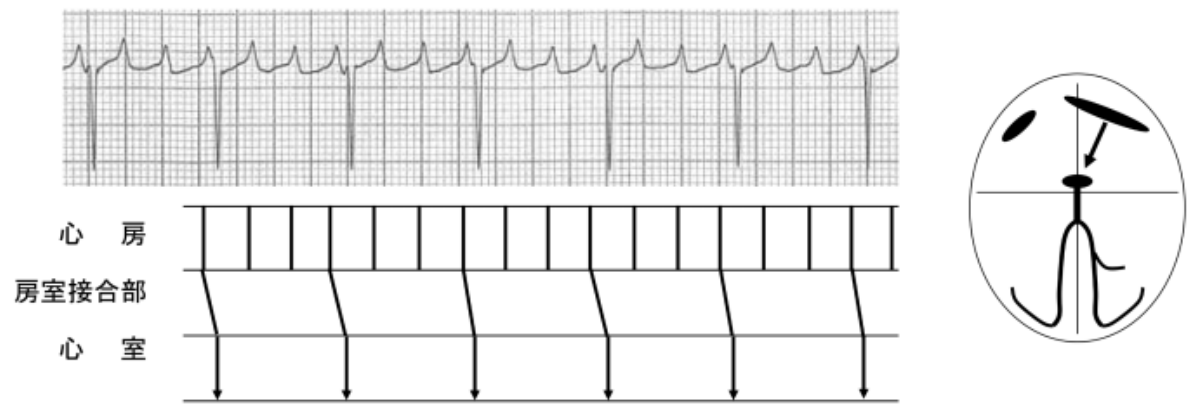

図16 心房粗動のメカニズム

心房細動とは異なり，F波と呼ばれるノコギリ状の矩形波が特徵である. 2: 1, 3: 1, $4: 1$ な ど心室への伝導頻度が一定しない事もあるが，一定の規則性が見られる.

性は見られない。III度房室ブロックは直ちに治療が必要 であり，発見したら直ちに医師に報告するべきである。

3. 心房細動 (atrial fibrillation: Af) - 心房粗動 (atrial fflutter : $\mathrm{AF})$

\section{(1) 心房細動}

心房細動は心房内のいたるところから刺激が発生し, 有効な心房の収縮を起こさない状態で，そのうちのどれ かがたまたま心室に伝わっている状態をいう。図15に示 すように，心電図上ではP波は認められず，f波と呼ばれ る細かいフレが見られ，QRS波は不規則なリズムとなる。

この状態では心拍出量が減少するといわれるが，極端 な頻脈や除脈にならない限り運動の中止とはならない。 しかし，心房内に血栓を形成しやすく，心源性脳梗塞と なる場合があるので注意が必要である。理学療法士とし
ては，突然に頻脈や除脈になったとき，あるいは，今ま で正常調律であったものから新たに発生したときには医 師に報告するべきである。心房細動は比較的リウマチ性 心臓弁膜症や, 僧帽弁狭窄症に圧倒的に多いといわれて きた，しかし最近の報告では非弁膜性心房細動が多く なっており，心源性脳梗塞の増加が問題となっている。

(2)心房粗動

心房粗動では心房が250〜300回／分もの規則的な興奮 を特徵としており，心電図上では心房細動のf波に対し て，のこぎり状のF波（大文字のFで表される）を示すの が特徵である。また心房細動と異なり規則性が見られる ため, 4:1の伝導では一見正常調律のように見えるため 鑑別が重要である。 特に, $2: 1$ や 1 : 1伝導となる心房 粗動では著しい頻脈（150拍／分以上）となり，激しい動 悸とともに心拍出量は減少をきたすため, めまいや動悸 
を訴える。図15は3：1伝導の心房粗動である。心房粗動 の頻脈発作を見たときは直ちに治療が必要となる。その ため, この不整脈を見つけたときには, 運動療法を中止 し医師に報告する必要がある。

\section{V. まとめ}

以上, 代表的な不整脈である期外収縮や房室ブロック， 心房細動・粗動を中心に, そのメカニズムと理学療法士 としての対処方法を解説した。

我々, 理学療法士として最も重要となるのは, 「運動療 法はすべからず運動負荷である」ということを意識し， 患者に行った運動がどの程度の負荷になっているのかを 意識することである。また，リスク管理を考える上で最 も問題となるのは, 患者の反応や症状に対して過剩に反 応し, 理学療法の介入が遅れde-conditioningに陥る事は避 けなければならない事である。そのためには，離床時期
の判断について医師や看護師と十分に議論を重衩，早期 からの理学療法介入を実施することが大切である。起こ りうるマイナス要因に対して十分に検討を重㸚た上で, 「一歩踏み込んだ理学療法介入」が求められている。

\section{引用文献}

1) 山田純生 : 理学療法士としての心疾患運動療法一の参画. 心 臓リハビリテーション, 1998，3(6)：8-14.

2) 牧田 茂: 不整脈. 総合リ八, 2003，31(2)：153-159.

3) 野原隆司: 合併症のある虚血性心疾患の運動療法一心室性不 整脈之運動療法一. Heart View, 1999, 3(8)：60-63.

4) 理学療法科学学会監修: 循環器系理学療法学入門. アイペッ ク, 東京, 2002 .

5) 小沢友紀雄 : 心電図トレーニング, 改訂6版. 中外医学社, 東 京, 2002 .

6) 五十嵐政夫, 山科 章: 不整脈の診かたと治療, 第 5 版. 医 学書院, 東京, 1999. 